\title{
FAMILY JUSTICE AND FAMILY VALUES ACCORDING TO LORD DENNING
}

\author{
M. D. A. Freeman
}

As we have searched for family justice in recent years, we have constantly been reminded of the need to uphold "family values." This exhortation post-dates Lord Denning's long judicial tenure, but will resonate with any student of Lord Denning for his was a voyage to a land where family justice was imbricated with family values. Lord Denning, we can be sure, would have joined in the debates on child support and child murderers, on divorce reform and cohabitation, on transsexualism and homosexuality, with vigour and vision. On some of these issues his views would have been predictable: on others less so. Few English judges have had a clearer world-view and perhaps none has had one in which the family was so central. This is not to say he held a consistent theory as such either about the family or the role of family law. And, indeed, there are contradictions: for example, he professes a belief in women's equality (though on one famous public occasion he castigated its implications ${ }^{2}$ ), yet is responsible for some notable patriarchal reasoning ${ }^{3}$ and some overtly sexist rulings. ${ }^{4}$

Lord Denning is a moral fundamentalist. Moral fundamentalism is part of the ethos of conservatism. ${ }^{5}$ It is a world-view firmly located within the traditional middle-classes. Stuart Hall has suggested that commitment to such values is sustained by a "sense of Englishness." "Englishness" is built around a cluster of core beliefs, characterised as the "Protestant Ethic." 7 These beliefs, about the value of hard work, delayed gratification, honesty, social discipline, respectability, etc, are inextricably

\footnotetext{
* Professor of English Law, University College, London.

${ }^{1}$ Michael Freeman, "Family Values and Family Justice" (1997) 50 Current Legal Problems 315.

${ }^{2}$ The Equality of Women (University of Liverpool Press, Liverpool, 1960).

${ }^{3}$ Wachtel v. Wachtel [1973] Fam. 72 at 94, quoted below, is the most overt.

${ }^{4}$ See, for example, Peake v. Automative Products Ltd. [1978] Q.B. 233.

${ }^{5}$ See R. Wallis, 'Moral Indignation and the Media: An Analysis of The National Viewers' and Listeners' Association" Sociology, vol.10, pp.271-295.

${ }^{6}$ Policing The Crisis: Mugging, the State and Law and Order (Macmillan, 1978).

${ }^{7}$ See Max Weber, The Protestant Ethic and the Spirit of Capitalism (translated by Talcott Parsons) (Routledge, 1930).
} 


\section{DENNING LAW JOURNAL}

bound up with the family, for it is there that these constraints are taught and generated. Lord Denning oozes traditional Englishness, as a reading of his Family Story amply testifies. ${ }^{8}$ His opinions on matters relating to personal life, to women, to the family (as also views on the black population and Jews ${ }^{9}$ ) are very much those of the traditional middle classes. His views about the equality of women have mellowed, though they have not matured, since he gave the Eleanor Rathbone Memorial Lecture in $1960 .^{10}$ His pronouncements on sexual morality, prudish, almost prurient, betray "a strong streak of nineteenth-century morality,"11 but this is a morality still firmly embedded within the moral centre of society. Examples are his views on artificial reproductive methods, ${ }^{12}$ on pornography (endorsing Raymond Blackburn's views ${ }^{13}$ ) and his dissent in Bravery v. Bravery. ${ }^{14}$ In this case he expressed the view that a husband who had a vasectomy without just cause or excuse was striking "at the very root of the marriage relationship." 15 He also articulates a view of family law, seeing it as like the criminal law in that in both regard has to be had to the "public interest."16

Lord Denning has clearly seen himself as a champion of the cause of women. He believes women have now attained complete equality. ${ }^{17}$ But he accepts totally sex-role stereotyping. Thus, writing in 1979, he saw men and women as occupying separate spheres. ${ }^{18}$ Nor is it likely that he would accept the part played by judicial pronouncements in constructing and defining the order to which he refers. The legal form is one of the main forms of social practice through which actual relationships embodying sexual stratification have been expressed. The legal system is a cultural underpinning of patriarchy. ${ }^{19}$ A number of Lord Denning's judgments can be read in this light. His justification of the resurrection of the "one-third rule" in Wachtel v. Wachtel is only the best-known example

\footnotetext{
${ }^{8}$ Lord Denning, The Family Story (Butterworths, 1981). His choice of music and literature (at pp. 249-250) is quintessentially English - and very middle-brow.

${ }^{9}$ See The Independent, 17 th August, 1990.

${ }^{10}$ Supra n.2.

${ }^{11}$ Robert Stevens, Law and Politics: The House of Lords As A Judicial Body (Weidenfeld and Nicolson, 1979), at p.500.

${ }^{12}$ H.L. Deb. vol. 207, col. 943 (26th February, 1958)

${ }^{13}$ R. v. Metropolitan Police Commissioner ex parte Blackburn (No.3) [1973] 1 Q.B. 241 at 248.

${ }_{14}^{14}$ [1954] 3 All E.R. 59 (and see H.L. Deb. vol. 206 col. 807 (4th December, 1957)).

${ }^{15}$ lbid at p.68.

${ }^{16}$ Idem.

${ }^{17}$ The Due Process of Law (Butterworths, 1980), at p.201.

${ }^{18}$ Ibid 194 at p.201.

${ }^{19}$ See M.D.A. Freeman, "Violence Against Women: Does The Legal System Provide Solutions or Itself Constitute The Problem?" (1980) 7 Br. J. of Law and Soc. 215.
} 


\section{FAMILY JUSTICE AND FAMILY VALUES}

of this. ${ }^{20}$ Another is found in the case of Button v. Button. There, he noted:

"A wife does not get a share in the house simply because she cleans the walls or works in the garden or helps her husband with the painting or decorating. Those are the sorts of things which a wife does for the benefit of the family without altering the title to or interests in the property." 21

It is instructive to compare his reasoning in Button and that in Cooke v. Head, four years later. ${ }^{22}$ The case concerned cohabitants: Ms. Cooke did "quite an unusual amount of work for a woman," 23 in helping Mr. Head build a bungalow which was to be their home. In Lord Denning's words:

"she used a sledgehammer to demolish some old buildings. She filled the wheelbarrow with rubble and hard core and wheeled it up the bank. She worked the cement mixer which was out of order and difficult to work. She did painting and so forth. Miss Cooke did much more than most women would do., 24

She had, it seems, the skills of a craftsman. ${ }^{25}$ What women normally do, or are expected to do, has, in Lord Denning's eyes, no economic value. But "real" work must be compensated. Mrs. Button got nothing: Ms. Cooke's share in the proceeds of sale of the bungalow was increased from one-twelfth to one-third.

To Lord Denning's way of thinking, women ought only to acquire rights in the matrimonial home when they have done something to merit them.

Button v. Button illustrates this: so, in a rather different way, does Gurasz v. Gurasz. ${ }^{26}$ The husband and wife jointly owned the matrimonial home, but the wife left with the four children because of her husband's repulsive conduct. The wife sought an order that her husband should leave the matrimonial home. It was granted. The Court of Appeal, however, rightly held that the order could not be supported on the ground that it was made. As Lord Denning said, the 1967 Act only protected a wife who had "no proprietary, contractual or statutory right to remain in the matrimonial

\footnotetext{
${ }^{20}$ Supra n.3.

${ }^{21}$ [1968] 1 All E.R. 1064 at 1067.

22 [1972] 2 All E.R. 38.

${ }^{23} \mathrm{Ibid}$ at p. 40 .

24 Ibid.

${ }^{25}$ Emphasis added.

${ }^{26}$ [1969] 3 All E.R. 822.
} 
home," what he called, somewhat pruriently, a "bare" wife. ${ }^{27}$ The judge's order was, however, supported on the ground that an innocent wife has a personal right to remain in the matrimonial home. Lord Denning reasoned:

"some features of family life are elemental in our society. One is that it is the husband's duty to provide his wife with a roof over her head: .... So long as the wife behaves herself, she is entitled to remain in the matrimonial home..... So long as she has done nothing to forfeit that right, the court will enforce it.,"28

Lord Denning's conclusion cannot be faulted. But his language is insensitive. To premise protection upon behaviour is to designate a wife as having a status similar to a child: we talk of children behaving but not, I think, wives.

These property cases demonstrate the conditional nature of the rights Lord Denning is prepared to bestow on women. His is the sort of reform which improves the position of some women while at the same time perpetuating the view that domestic labour has no economic value, and rights generally are dependent on moral proprieties. It is as well to remind ourselves of this for Lord Denning has often been seen, and has publicised himself, as in the vanguard of reform. There has been legislative reform to recognise the value of domestic labour, ${ }^{29}$ and to preserve maintenance and accommodation rights after matrimonial misconduct, ${ }^{30}$ but these, it must be stressed, were reforms to reverse trends effectuated by Lord Denning.

There is hardly an area of modern family law upon which Lord Denning has not pronounced at some time or other. He sat as a judge in the Probate, Divorce and Admiralty Division for eighteen months in 1944 and 1945. Very few judgments of his of this period are reported. He seems to have been reversed only once. ${ }^{31}$ His reported judgments of the period do not throw much light on his values or his methodology. But they show him to be homely and down-to-earth (sex is described as a "natural and healthy way of living"32); prepared to dispose of seemingly binding cases where they appear to him to lack any rationale $;^{33}$ with an eye for law

\footnotetext{
${ }^{27}$ Ibid at p.824.

${ }^{28}$ Ibid at p.823.

${ }^{29}$ Matrimonial Proceedings and Property Act, 1970, s.5(1)(f)

${ }^{30}$ Domestic Proceedings and Magistrates' Courts Act 1978.

${ }^{31}$ Churchman v. Churchman [1945] P. 44.

${ }^{32}$ Fletcher v. Fletcher [1945] 1 All E.R. 582.

33 An example is Norton v. Norton [1945] P. 56.
} 
reform. ${ }^{34}$ He also demonstrated the ability to research difficult points of law: as a result of one such exercise in a case ${ }^{35}$ which demanded that the principles of collusion be stated, he wrote an article on the subject of presumptions and burdens which was published in the Law Quarterly Review. ${ }^{36}$ There are glimpses also of his pragmatic approach to problems.

"Thank Goodness I only did Divorce for 18 months," he comments on his brief sojourn in the P.D.A. ${ }^{37}$ But, ironically, within ten months he was chairing a committee to inquire into divorce procedure. This was responsible for reducing the period between decree nisi and absolute, for the establishment of commissioners to try divorces and for a strengthening of welfare services in the divorce process. ${ }^{38}$ He was to emphasise the importance of reconciliation many times in later cases. ${ }^{39}$ Between 1948 and 1957 he sat on a large number of appeals in family matters. This is the time when the deserted wife's equity emerged, ${ }^{40}$ the notion of "family assets" was born, ${ }^{41}$ when the courts began to liberalise the bars to divorce. ${ }^{42}$ Lord Denning is the progenitor of the first two of these concepts, and played a major role in the third. One of his earliest reported forays into family law in the Court of Appeal is Hopes v. Hopes. ${ }^{43} \mathrm{He}$ recognised the social realities of the housing shortage.

Lord Denning's reputation as the "great dissenter" is not borne out by the facts in his early years in the Court of Appeal. It was six years before he dissented in a Court of Appeal case concerned with family matters. By then he had Bendall v. McWhirter ${ }^{44}$ and Rimmer v. Rimmer, ${ }^{45}$ two breakthrough family property cases, behind him, and in both, as in all family law cases until Bravery v. Bravery, ${ }^{46}$ the court was unanimous. Indeed, it was 1956 before he dissented again, and his conclusion was an eminently sensible one. ${ }^{47}$

\footnotetext{
${ }^{34}$ In Norton v. Norton ibid he disapproves of the way the respondent and correspondent deny adultery solely to dispute damages and comments "the practice should be changed."

${ }^{35}$ Emanuel v. Emanuel [1946] P. 115.

36 "Presumptions and Burdens" (1945) 61 L.Q.R. 379.

${ }^{37}$ Supra n.17 at p.189.

${ }^{38}$ The product of three reports: Cmd. 6881; Cmd. 6945; and Cmd. 7024.

${ }^{39}$ See McTaggart v. McTaggart [1948] P. 94; Simpson v. Simpson [1954] 1 W.L.R. 994; Richardson v. Richardson [1949] P.16.

${ }^{40}$ See Bendall v. McWhirter [1952] 2 Q.B. 466.

${ }^{41}$ See Rimmer v. Rimmer [1953] 1 Q.B. 63.

${ }^{42}$ See, e.g., Douglas v. Douglas [1950] P. 85.

43 [1949] P. 227.

44 Supra n.40.

${ }^{45}$ Supra n.41.

${ }^{46}$ Supra n.14.

${ }^{47}$ Jefferson v. Jefferson [1956] P. 136 (the logic of a statutory provision appiicable to large maintenance payments applied to a small one).
} 
In his five years in the House of Lords, he had no opportunity to pronounce in a judicial capacity upon any family law matters. He became an active member of the legislative branch of the House of Lords. ${ }^{48}$ Often his speeches were an affirmation of traditional values including matters relating to family life and sexual morality. ${ }^{49}$

By the time he returned to the Court of Appeal as Master of the Rolls he had established a reputation for dissent and controversy (though Lord Keith in fact dissented more often). ${ }^{50}$ He became less cautious, less concerned with precedent and logical development. Though a conservative through and through, he committed himself to change, to right injustice. The paradox is more apparent than real for reform required the re-establishment of traditional values. A dominant theme running through Lord Denning's crusades in this period has been to protect the small man against large organisations, bureaucracies and government bodies. ${ }^{51}$ In family law the small man has often been the small woman. Williams and Glyn's Bank v. Boland is a good illustration of the way Lord Denning's concern to protect the individual's interests against the power of large organisations has reflected itself in his family law thinking. ${ }^{52}$ The husband had raised money for his business on the security of the matrimonial home. The wife had made substantial contributions to its purchase and was, it was clear, entitled to a share in it. The business failed, and the bank sought to enforce their charges. The case turned on whether the wife was in "actual occupation" of the house. To Templeman J. only the mortgagor (the husband) was: any other view would "lead to chaos." 53 The Court of Appeal, Lord Denning very much to the fore, disagreed. Lord Denning was concerned that: "we should not give monied might priority over social justice." He reasoned:

\begin{abstract}
"Anyone who lends money on the security of a matrimonial home... ought to realise that the wife may have a share in it ... It seems to me utterly wrong that a lender should turn a blind eye to the wife's interest or the possibility of it - and afterwards seek to turn her and the family out - on the plea that he did not know that she was in actual occupation. If a bank is to do its duty, in the
\end{abstract}

\footnotetext{
${ }^{48}$ L. Blom-Cooper and G. Drewry, Final Appeal (Clarendon Press,1972), at p.205 show him to be the most active participant in House of Lords' debates of all eligible judges.

${ }^{49}$ See especially his speech reported at H.L. Deb. vol. 207 col. 943 (26th February, 1958).

${ }^{50}$ See supra n.48 at p. 179: only 16\% of Lord Denning's judgments were dissents and $22 \%$ of Lord Keith's were.

${ }^{5 t}$ But not consistently so: see R. v. Preston S.B.A.T. ex parte Moore [1975] 1 W.L.R. 624.

52 [1979] 2 W.L.R. 550.

${ }^{53}$ See Bird v. Syme-Thompson [1979] 1 W.L.R. 440 at 444.
} 


\section{FAMILY JUSTICE AND FAMILY VALUES}

society in which we live, it should recognise the integrity of the matrimonial home."

Boland was the 1970s' counterpart to the deserted wife's equity of the 1950s and early 1960s, which the House of Lords extirpated in National Provincial Bank v. Ainsworth. ${ }^{55}$ But protection of the wife in Boland required statutory construction, not judicial intervention. It is not surprising that the House of Lords upheld Boland. ${ }^{56}$

Boland is a good illustration of Lord Denning's concerns towards the end of his time in the Court of Appeal. But it is not an especially good illustration of his reasoning processes. It is to other family law decisions, particularly to those of the 1960s and early 1970 s, that one must go to seek these. After the early 1970s, Lord Denning made only occasional forays into family matters: Boland is one example, Davis v. Johnson was another ${ }^{57}$ Here in his view it was imperative that "social justice require[d] that personal rights should ... be given priority over rights of property." ${ }^{58}$ He referred to Tarr v. Tarr ${ }^{59}$ and National Provincial Bank v. Ainsworth ${ }^{60}$ and commented:

"I know that in those two cases the House of Lords reversed the decisions of this court and gave priority to property rights. But Parliament in each case afterwards passed laws so as to restore the decisions of this court. I prefer to go by the principles underlying the legislative enactments rather than by the out-dated notions of the past." ${ }^{, 61}$

It is noteworthy that on this occasion one member of the House of Lords, Lord Scarman, picked up Lord Denning's point, noting that "the restriction or suspension for a time of property rights is a familiar aspect of much of our social legislation." 62

Lord Denning made his major impact on family law in a series of cases about the ownership of the matrimonial home in the years immediately after Ainsworth. It would be reading too much into these decisions to say that they were a direct reaction to the House of Lords' demolition of the

\footnotetext{
${ }^{54}$ Supra n.52 at p.560.

${ }^{55}$ [1965] A.C. 1175.

${ }^{56}$ [1981] A.C. 487.

${ }^{57}$ [1978] 1 All E.R. 841.

${ }^{58}$ Ibid at p.849.

${ }^{59}$ [1973] A.C. 254.

${ }^{60}$ Supra $\mathrm{n} .55$.

${ }^{61}$ Supra $\mathrm{n} .57$ at $\mathrm{p} .847$

${ }^{62}$ [1979] A.C. 264.
} 
deserted wife's equity, but this might be a plausible interpretation. The passage of legislation giving judges discretion to transfer property and vary property interests may have taken the sting out of Lord Denning's campaign and encouraged him to innovate in other fields. ${ }^{63}$ Certainly, after establishing precedents on financial provision and property adjustment on divorce, in the light of Acts which had, in his language, "revolutionised the law,"64 he sought other pastures. Boland excepted, his main interest in the family, as the 1970s developed, really lay in assimilating wherever possible the consequences of cohabitation to those of marriage.

But he regretted that, as he put it, the concept of marriage was being "eroded." His statement in Bernard v. Josephs did not disguise his own sadness: "Many couples lived together as if they were husband and wife when they were not married." ${ }^{, 65}$ In The Due Process of the Law he wrote that "the only basis for a sound family life is a Christian marriage....,66 The sentiments are congruent with his moral fundamentalism, to which reference has already been made. With this in mind, his response to situations where cohabitation has broken down may cause surprise. It might be expected that he would have adopted the view that the law should only afford protection and relief to those lawfully married. But Lord Denning's response - indeed, the judicial response - has been to treat cohabiting couples like married couples wherever possible. ${ }^{67}$ The judiciary has not done this with every relationship outside marriage: only with those that conform stereotypically to norms associated with marriage. Thus, the retaining of separate names or separate bank accounts may induce the courts to treat a relationship as contractual and not to impose upon it consequences that flow from status. ${ }^{68}$ The female cohabitant's behaviour is scrutinised: has she done the sort of things that a married woman might be expected to do or has she exceeded expectations in some way (the example of building activities already referred to). ${ }^{69}$ Her sexual fidelity is also examined rather as a married woman's was under the old

\footnotetext{
${ }^{63}$ Matrimonial Proceedings and Property Act 1970, s.4.

${ }^{64}$ Trippas v. Trippas [1973] 2 All E.R. 1 at 4.

${ }^{65}$ [1982] 3 All E.R. 162 at 165.

${ }^{66}$ Supra n.17 at p. 201.

${ }^{67}$ See, generally, M.D.A. Freeman and C.M. Lyon, Cohabitation Without Marriage (Gower Press, 1983) chs. 4 and 6.

${ }^{68}$ See, e.g., Helby v. Rafferty [1979] 1 W.L.R. 13, not a decision of Lord Denning's.

${ }^{69}$ As in Cooke v. Head and Eves v. Eves, see supra n.22 \& infra n.76. But see also Smith v. Baker [1970] 2 All E.R. 826 ("she even helped dig the foundation herself" per Lord Denning at p.827).
} 


\section{FAMILY JUSTICE AND FAMILY VALUES}

fault-based law of divorce. ${ }^{70}$ What superficially looks progressive, on closer examination is more suspect.

In Cooke v. Head, ${ }^{71}$ Lord Denning treated an unmarried couple in the same way as he treated the married in such cases as Hazell v. Hazell, ${ }^{72}$ Cracknell v. Cracknell ${ }^{73}$ and Hargrave v. Newton. ${ }^{74}$

"It is now held that, whenever two parties by their joint efforts acquire property to be used for their joint benefit, the courts may impose or impute a constructive or resulting trust. The legal owner is bound to hold the property on trust for them both. This trust does not need any writing. It can be enforced by an order for sale .... It applies to husband and wife, to engaged couples, and to man and mistress, and maybe to other relationships too." 75

In Eves v. Eves,${ }^{76}$ Cooke v. Head was followed. Lord Denning quoted his remarks in Cooke v. Head. He referred particularly to the male cohabitant's conduct: how he gained her confidence and how she trusted him. He had gained her compliance by a statement that he intended to put the property into their joint names as soon as it was legally possible. Lord Denning thought that "he should be judged by what he told her - by what he had led her to believe - and not by his own intent which he kept to himself."

"It is clear that her contribution was such that if she had been a wife she would have had a good claim to have a share in [the house] on a divorce."

He cited Wachtel v. Wachtel in support. ${ }^{79}$ In both Cooke v. Head and Eves v. Eves, the female cohabitant was held to have acquired an interest by way of a trust. The two cases show the way the courts, with Lord Denning very much in the vanguard, are developing principles for

\footnotetext{
${ }^{70}$ See Ruth Deech, "The Case Against the Legal Recognition of Cohabitation" (1980) 29 I.C.L.Q. 480 .

${ }^{7}$ Supra n.22.

72 [1972] 1 W.L.R. 301

${ }^{73}$ [1971] P. 356.

${ }^{74}$ [1971] 2 All E.R. 1611.

${ }^{75}$ Supra n.22 at p.41.

${ }_{77}^{76}[1975] 1$ W.L.R. 1338.

77 Ibid at p.1342.

${ }^{78}$ Idem.

${ }^{79}$ Supra n.3.
} 
drawing inferences from the relationships of cohabitants in much the same way as they have done in the case of husband and wife.

Having implied a trust, within days, Lord Denning went on to imply a contract. In Tanner $v$. Tanner, the male partner had purchased a house for the defendant and their twin baby daughters. ${ }^{80}$ She had left her rentcontrolled flat. When the relationship broke down the plaintiff claimed possession of the house on the basis that the defendant had a bare licence only, which he had revoked. Lord Denning's riposte was:

"I cannot believe that this is the law. The man had a moral duty to provide for the babies of whom he was the father. I would go further. I think he had a legal duty towards them. Not only towards the babies. But also towards their mother. She was looking after them and bringing them up. In order to fulfil this duty towards the babies, he was under a duty to provide for the mother too., 81

A contractual licence was inferred, consideration being found in the defendant's giving up of her rent-controlled flat. Lord Denning went even further: the court, he argued, could not only imply a contract but if need be, impose the equivalent of a contract. ${ }^{82}$

In Cooke v. Head, the Court of Appeal refused to follow a previous Court of Appeal decision. They did not say they were doing this but simply decided the instant case as if the earlier one were not there. Lord Denning admitted this in Dyson Holdings v. Fox, ${ }^{83}$ another case on cohabitation, in which he refused to follow Gammans v. Ekins. ${ }^{84}$ The previous decision, he said, was "not in accord with modern thinking.,"85 Lord Denning's judgment in Dyson Holdings v. Fox is a good illustration of his thinking. The question which arose was whether a seventy-four year old woman who had lived with a man for twenty-one years, the cohabitation having terminated on his death some fourteen years earlier, could be turned out of a house she had occupied for thirty-five years, by a property company. There was no doubt where Lord Denning's sympathy lay. She could stay if she were a member of her former cohabitant's family. Existing case law would have allowed the court so to hold had they had children. ${ }^{86}$ But they had not. Lord Denning thought this "a

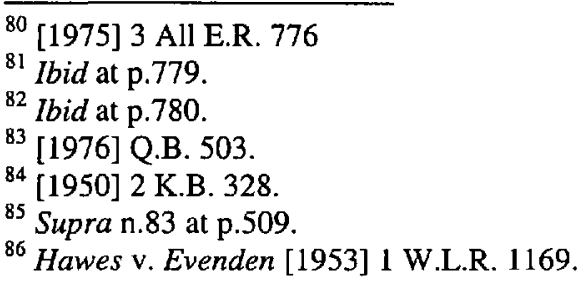




\section{FAMILY JUSTICE AND FAMILY VALUES}

ridiculous distinction. So ridiculous, indeed, that it should be rejected by this court." ${ }^{87}$ So, what was to be done with the previous case law? Lord Denning had two answers. First, to assert in his grand style that the Court of Appeal was not bound by previous decisions which, as a result of a change in social conditions, were not in accord with modern thinking. And, secondly, to demonstrate, rather deviously, that Gammans v. Ekins could be disposed of by one of the exceptions laid down in Young v. Bristol Aeroplane Co. ${ }^{88}$

Lord Denning made a major contribution to divorce jurisprudence. His own attitude towards divorce was always ambivalent. He favoured divorce reform both in $1963^{89}$ and in $1969 .^{90}$ In his judicial capacity he enthusiastically embraced the irretrievable breakdown concept. ${ }^{91}$ On the other hand, he was clearly fearful of what divorce reform might mean for the family. Speaking to the Nottingham branch of the Marriage Guidance Council in 1971 he warned: "It is a time for all good folk to take a stand, else the permissive society will soon become the decadent society." concerns were apparent in his decisions long before this. ${ }^{93}$ Thus, in Kaslefsky v. Kaslefsky in 1950 he stressed that gross neglect and chronic discord were not yet grounds for divorce:

"If the door of cruelty were opened too wide, we should soon find ourselves granting divorce for incompatibility of temperament. That is an easy path to tread... The temptation must be resisted lest we slip into a state of affairs where the institution of marriage itself is imperilled." 94

Lord Denning never liked divorce and always wanted to keep it firmly within bounds. But he took a realistic approach to it. And he was sometimes ahead of his time. In 1950, he stressed that the divorce court was concerned not to punish anyone, but to give relief from a marriage that had broken down. ${ }^{95}$ He found the concept of mutual desertion acceptable for much the same reason. Thus, in Beigan v. Beigan, he stated:

\footnotetext{
${ }^{87}$ Supra n.83 at p.509.

88 [1944] K.B. 718.

${ }^{89}$ See H.L. Deb. vol. 250 cols. 405-407.

${ }^{90}$ See B.H. Lee, Divorce Reform In England (Peter Owen, 1974) at pp.179-80. But $c f$. his foreword to W. Latey, The Tide of Divorce (Longman, 1970) at p. vii.

${ }^{91}$ See, e.g., Fuller (orse Penfold) v. Fuller [1973] 2 All E.R. 650.

${ }^{92}$ The Times, 1st October, 1971.

${ }^{93}$ Moor v. Moor [1954] 2 All E.R. 458; Pike v. Pike [1953] P. 38

${ }^{94}$ [1950] 2 All E.R. 398 at 403.

${ }^{95}$ Davis v. Davis [1950] P. 125.
} 
"In many of these cases both are equally to blame for the breakdown of the marriage and the only just solution is a decree of divorce on the ground of desertion by each without drawing any distinction between them.,"96

His pronouncements on reconciliation were also ahead of his time. Thus, in Richardson v. Richardson in 1949, his view on what conduct could revive condoned adultery was influenced by considering what would foster and what frustrate attempts at reconciliation. ${ }^{97}$ And, in Simpson v. Simpson in 1954 - an application for leave to petition for divorce within three years of marriage - he stressed the importance of looking at the respondent's answer as well as the petitioner's allegations. ${ }^{98}$ Without so doing, it was difficult to assess the possibility of a reconciliation between the parties. There is little doubt, though, that Lord Denning's major contribution to divorce law in these pre-reform days was the establishment of a civil law test in relation to the proof of matrimonial offences. ${ }^{99}$

To each of the old grounds of divorce, the now moribund "facts," Lord Denning contributed significantly. He heard the first appeal on adultery in its new guise under the Divorce Reform Act 1969 and held that the two limbs of section 1(2)(a) were independent, so that the linking "and" was construed disjunctively. ${ }^{100}$ A differently constituted Court of Appeal was not happy with this conclusion but unprepared to believe that a court containing Lord Denning and Lord Justice Scarman could have nodded. ${ }^{101}$ Lord Denning heard only one reported appeal on "unreasonable behaviour," the case of Bradley v. Bradley. ${ }^{102}$ This showed Lord Denning at his liberal and pragmatic best. A woman continued to live with her husband because she had a large number of children and nowhere else to go. There was no doubt that his behaviour (which included violence) was such that she could not reasonably be expected to live with him. She was in a "Catch-22" situation: the local authority would rehouse her if she secured a divorce, but to obtain a divorce did she first have to separate from her husband? The trial judge took the view that there was no possibility of a divorce. Lord Denning, however, reasoned:

\footnotetext{
${ }_{96}^{96}[1956] 2$ All E.R. 630 at 632.

${ }^{97}$ [1949] P. 16.

98 [1954] 1 W.L.R. 994

${ }^{99}$ Gower v. Gower [1950] W.N. 156. See also Blyth v. Blyth [1966] A.C. 643.

${ }^{100}$ Cleary v. Cleary [1974] 1 All E.R. 498.

${ }^{101}$ Carr v. Carr [1974] 3 All E.R. 1193.

${ }^{102}$ [1973] 3 All E.R. 750.
} 
"...the wife is in fact living with the husband. How can she say that she "cannot reasonably be expected to live with her husband' when she is in fact living with him? I think she can say so. The section does not go on to provide that she must have left him and be 'living apart' from him. It simply says that she 'cannot reasonably be expected to live with him.' I think she satisfies that requirement, even though she is in the same house with him - and is in fact living with him - if it be the case that she has no alternative open to her - nowhere else to go. It is not reasonable to expect her to live there, but albeit unreasonable, she has no option but to be there."103

On desertion too Lord Denning made a major contribution. Until Lord Denning held otherwise, it was the law that a husband had an overriding right to determine the location of the matrimonial home and a wife who refused to join him there was said to be in desertion. ${ }^{104}$ But, in Dunn v. Dunn, ${ }^{105}$ he held that it was the party who had "produced the separation by reason of his or her unreasonable behaviour" 106 that was in desertion. His other principal contribution to the law of desertion is his judgment in Hopes v. Hopes. ${ }^{107} \mathrm{He}$ drew a distinction between desertion on the one hand and gross neglect and chronic discord on the other. When a couple were living under the same roof, separation for the purposes of desertion occurred "when they cease to be one household and become two households..." 108 The "one household or two" test has been consistently invoked ever since. ${ }^{109}$

Lord Denning's impact on the separation provisions of the Divorce Reform Act 1969 was not great, though his intelligent and expansive interpretation of what is now section 2(6) of the Matrimonial Causes Act 1973 in Fuller (orse Penfold) v. Fuller should not be overlooked. ${ }^{110}$ It undoubtedly gave effect to the policy underlying the five years separation provision. So did his judgment in Chapman v. Chapman: in a five years separation petition "it would be contrary to the policy of the legislature that the court should hold a post-mortem simply to make an award of costs."

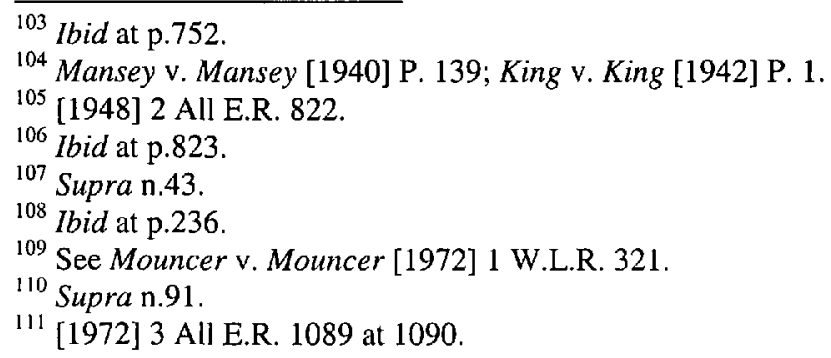




\section{DENNING LAW JOURNAL}

Lord Denning's contribution to the law on financial provision after divorce is considerable. He was one of the first to recognise that a wife might ask for maintenance even if she was "guilty." He developed the notion of the "compassionate allowance." 12 He recognised the need to take account of the wife's earning capacity though he affirmed in the same case the importance of female dependency ("It does not... lie in the mouth of a wrongdoing husband to say that his wife ought to go out to work simply in order to relieve him from paying maintenance"113). Lord Denning was one of the earliest judicial advocates of the clean break ${ }^{114}$ and, once its principle was established, ${ }^{115}$ he gave it his support, though some ambivalence can be detected. ${ }^{116} \mathrm{He}$ saw the necessity to treat financial provision and property adjustment as all of one piece ${ }^{117}$ before legislation in 1970 did just this. But of all his decisions on financial provision it is Wachtel $\mathrm{v}$. Wachtel for which he will be longest remembered. ${ }^{118}$ It is true that it was Ormrod J. in Wachtel who coined the phrase "obvious and gross" misconduct ${ }^{119}$ and Phillimore L.J. in Ackerman v. Ackerman ${ }^{120}$ who re-introduced the one-third rule (whilst stressing it was not a rule). But Lord Denning's judgment remains the classical source of these doctrines. Wachtel is also significant for the stand that Lord Denning takes on lump sum payments. The concept dates from $1963^{121}$ but judges were reluctant to order such payments. Lord Denning stressed that: "In every case the court should consider whether to order a lump sum to be paid..." Of course:

"No order should be made for a lump sum unless the husband has capital assets out of which to pay it - without crippling his earning power.... When the husband has available capital assets sufficient for the purpose, the court should not hesitate to order a lump sum.,"122

\footnotetext{
${ }^{112}$ See Sydenham v. Sydenham [1949] 2 All E.R. 196; Trestain v. Trestain [1950] P. 198. See also Williams v. Williams [1957] 1 W.L.R. 148 (right to maintenance suspended, not forfeited, by desertion).

${ }^{113}$ Rose v. Rose [1950] 2 All E.R. 311 at 313.

${ }^{114}$ Smith v. Smith [1970] 1 W.L.R. 155.

${ }^{115}$ See Minton v. Minton [1979] A.C. 593.

${ }^{116}$ See Dunford v. Dunford [1980] 1 All E.R. 122. See also Jessel v. Jessel [1979] 3 All E.R. 645.

${ }^{117}$ In Button v. Button supra n.21 at p.1067.

${ }^{118}$ Supra n.3.

119 [1973] 1 All E.R. 113 at 119.

${ }^{120}$ [1972] Fam. 225 at 234.

${ }^{121}$ Matrimonial Causes Act 1963 s.5(1).

${ }^{122}$ Supra n.3 at pp.95-96.
} 
He saw it as helping to remove the bitterness so often attendant on periodical payments. Wachtel ensured that lump sums became common even if, necessarily, the number of orders is still comparatively small. Lord Denning only returned to the question once since Wachtel. In Trippas v. Trippas, he rejected the "suggestion that a lump sum is simply another way of quantifying maintenance." 123

Lord Denning's observations on matrimonial misconduct and his espousal of lump sum payments did much to chart the future, at least the immediate future, of financial provision and "equitable redistribution"124 of property on divorce. The same cannot be said of his reactivation of the discredited notion of the "one-third" rule. But his justification of the rule will long be remembered:

"When a marriage breaks up, there will thenceforward be two households instead of one. The husband will have to go out to work all day and must get some woman to look after the house - either a wife if he remarries, or a housekeeper, if he does not. He will also have to provide maintenance for the children. The wife will not usually have so much expense. She may go out to work herself, but she will not usually employ a housekeeper. She will do most of the housework herself, perhaps with some help. Or she may remarry, in which case her new husband will provide for her. In any case, when there are two households, the greater expense will, in most cases, fall on the husband rather than the wife. As a start has to be made somewhere, it seems to us that in the past it was quite fair to start with one-third."

Lord Denning did not then ask about the present.

Anyone who reads The Due Process of Law will be left in no doubt that Lord Denning himself thinks his most substantial venture into family law have been in connection with the matrimonial home. ${ }^{126}$ As early as 1947 he was protecting deserted wives in the occupation of the matrimonial home, and claiming that the discretion vested in the judge by section 17 of the 1882 Act was "in no way fettered, though it must be exercised judicially." 27 It was he who invented the "compendious phrase"128

\footnotetext{
${ }^{123}$ [1973] Fam. 134 at 140.

${ }^{124}$ The term is Ormrod L.J.'s: see O'Donnell v. O'Donnell [1976] Fam. 83.

${ }^{125}$ Supra n.3 at p.94.

${ }^{126}$ Supra n. 17 at part 6.

${ }^{127}$ Hutchinson v. Hutchinson [1947] 63 T.L.R. 645

${ }^{128}$ Nixon v. Nixon [1969] 3 All E.R. 1133 at 1137.
} 


\section{DENNING LAW JOURNAL}

"family assets" 129 (the House of Lords subsequently determined the expression had no legal meaning). ${ }^{130}$ Lord Denning's response was to construct a beneficial interest in the matrimonial home by imposing a trust. ${ }^{131}$ The problem centred on indirect contributions by the wife to the family budget. The orthodox view required the indirect contribution to be directly referable to the acquisition costs, ${ }^{132}$ but Lord Denning rejected the need to find such a causal relationship. In his view it was sufficient "if the contributions made by the wife are such as to relieve the husband from expenditure which he would otherwise have had to bear." Denning was also instrumental in establishing the principle that a wife may acquire an interest in the matrimonial home by working gratuitously in her husband's business. ${ }^{134}$ Another strategy adopted by Lord Denning to enable a non-estate owner to acquire interest in the matrimonial home is through effecting improvements to it. ${ }^{135}$ This led to a statutory formulation (section 37 of the Matrimonial Proceedings and Property Act 1970). He did not disguise his pleasure.

"Note that section 37 is not an alteration of the previous law. It is a declaration of the law - a declaration of what the law was before the Act. It affirms, therefore, the decision of this court in Jansen $\mathrm{v}$. Jansen and the principles adopted by the equitable school." ${ }^{136}$

Lord Denning also did much to protect the occupation in the matrimonial home of the deserted wife. Her right to stay in the matrimonial home as against her husband had been established before Lord Denning became a judge, ${ }^{137}$ but it was one he embraced enthusiastically. ${ }^{138}$ In a series of cases, beginning with Bendall $\mathrm{v}$. McWhirter in 1952 the courts, with Lord Denning very much in the

\footnotetext{
${ }^{129}$ First used in Cobb v. Cobb [1955] 1 W.L.R. 731 (though he claims in The Due Process of Law supra $\mathrm{n} .17$ at p.232 that he did so earlier in Rimmer v. Rimmer: the concept is there, but not the phrase).

${ }^{130}$ Pettitt v. Pettitt [1970] A.C.777 and Gissing v. Gissing [1971] A.C. 885.

${ }^{131}$ Heseltine v. Heseltine [1971] 1 W.L.R. 342; Hazell v. Hazell supra n.72; Davis v. Vale [1971] I W.L.R. 1022; Cooke v. Head supra n.22.

${ }^{132}$ Cowcher v. Cowcher [1972] 1 W.L.R. 425.

${ }^{133}$ Hazell v. Hazell supra $n .72$ at p.304.

${ }^{134}$ Nixon v. Nixon supra n.128; Muetzel v. Muetzel [1970] 1 W.L.R. 188 (a partnership); Re Cummins [1971] 3 All E.R. 782.

${ }^{135}$ Appleton v. Appleton [1965] 1 All E.R. 44; Jansen v. Jansen [1965] P. 478; cf. Button v.

Button supra $\mathrm{n} .21$.

${ }^{136}$ In Davis v. Vale supra n.131 at p.1025.

${ }^{137}$ Bramwell v. Bramwell [1942] 1 K.B. 370.

${ }^{138}$ In Hutchinson v. Hutchinson supra n.127; Lee v. Lee [1952] 2 Q.B. 489 at 492; and in Halden v. Halden [1966] 3 All E.R. 412 at 413.
} 
vanguard, went even further and created, what was known as, the "deserted wife's equity." "139 This was one of the boldest creations of the judiciary in this century. It survived until 1965, when, in National Provincial Bank v. Ainsworth, "140 "social considerations of humanity"141 ceded to justice to third parties and sound principles of real property law. And this was a catalyst to reform, but Lord Denning was critical of this reform too. In particular, he spoke against registration of a charge as a pre-requisite to protection. ${ }^{142}$

Lord Denning was also involved in a large number of decisions relating to children. Many of them are important, even if not recognised as such when they were decided. Most significant is the earliest case to move away from a presumption of reasonableness in withholding consent to adoption and to substitute an objective test in determining whether the parent's refusal is reasonable. Lord Denning said:

"A reasonable mother surely gives great weight to what is better for the child. Her anguish of mind is quite understandable; but still it may be unreasonable for her to withhold consent. We must look and see whether it is reasonable or unreasonable according to what a reasonable woman in her place would do in all the circumstances of the case." 143

These remarks were accepted as "authoritative" by Lord Hailsham in the leading case of $\operatorname{Re} W$ (an infant) in 1971 and Lord Denning's 1962 test remains the test today. ${ }^{144}$

Lord Denning participated also in one of the earliest children's rights cases (Hewer v. Bryant). ${ }^{145}$ His description of the parental right to physical possession of children as a "dwindling" one which starts "with a right of control and ends with little more than advice" remains memorable. ${ }^{146}$ There is here a nascent recognition of a child's autonomy. In several cases his concern for a child's welfare can be detected. ${ }^{147}$ Not surprisingly, Lord Denning's views on the family and his traditionalism

\footnotetext{
${ }^{139}$ Supra n.55.

${ }^{140}$ Ibid.

${ }^{141}$ Ibid at p.1242 per Lord Wilberforce.

${ }^{142}$ H.L. Deb. vol. 275 col. 44 (14th June, 1966).

${ }^{143} \operatorname{Re} L$ [1962] 106 S.J. 611

${ }^{144}$ [1971] A.C. 682

145 [1970] 1 Q.B. 357.

${ }^{146} \mathrm{Ibid}$ at p.369. See also $B(B R)$ v. $B(J)[1968]$ P. 466.

${ }^{147}$ For example, $\operatorname{Re} S$ (an infant) [1965] 1 W.L.R. 865. See also Surrey C.C. v. $S$ [1974] Q.B. 124.
} 
are reflected in decisions in child law matters. Thus, in $\operatorname{Re} L$, he denied an adulterous mother custody.

"It would be an exceedingly bad example if it were thought that a mother could go off with another man and then claim as of right to say: 'Oh well, they are my two little girls and I am entitled to take them with me. I can not only leave my home and break it up and leave their father, but I can take the children with me and the law will not say me nay.' It seems to me that a mother must realise that if she leaves and breaks up her home in this way she cannot as of right demand to take the children from the father." 148

It is significant that twice in this judgment he uses the expression "as of right," and that he went on to refer to the case as "a matter of simple justice" between mother and father. The matter should have been characterised, as it is now, as one concerned with children's welfare. ${ }^{149}$ Lord Denning's determination to punish a "loose woman" got the better of him, rather as it was to do in the notorious Bradford Teachers' Training College case. ${ }^{150}$ Other decisions, though less striking, nourish similar notions about family life. Thus, in $W$ v. $W$ and $C$, he asserted the "general principle" that it was better for a boy of eight to be with his father than with his mother, even if he had been brought up by his mother until then. ${ }^{151}$ This was soon disapproved of. ${ }^{152}$

He both extended and narrowed wardship jurisdiction. In $\operatorname{Re} P(G E)$ (infant) he held that the court had jurisdiction in respect of a stateless alien minor, who though not present in the jurisdiction would be said to be "ordinarily resident" in England. ${ }^{153}$ There was some authority in the law of treason for saying that an alien resident could owe allegiance even though he was outside the country, but, if the analogy is tenuous, Lord Denning was not deterred from making law. ${ }^{154} \mathrm{He}$ commented:

"We are not deterred by the absence of authority in the books. Our forefathers always held that the law was

\footnotetext{
${ }^{148}$ [1962] 3 All E.R. 1 at 3-4.

${ }^{149} S(B D)$ v. $S(D J)$ [1977] Fam. 109 and $R e K$ [1977] Fam. 179.

${ }^{150}$ Ward v. Bradford Corporation [1972] 70 L.G.R. 27 at 35.

${ }^{151}$ [1968] 1 W.L.R. 1310

${ }^{152}$ In $\operatorname{Re} C(A)$ (an infant) [1970] 1 All E.R. 309

${ }^{153}$ [1965] Ch. 568.

154 Joyce v. D.P.P. [1946] A.C. 347.
} 
locked in the breasts of the judges ready to be unlocked whenever the need arose."155

But Lord Denning cut down the ambit of the protective jurisdiction on at least three occasions: in each the public interest was involved. In $S \mathrm{v}$. $M c C,{ }^{156}$ a paternity dispute, the interests of justice prevailed over the interests of the child; in $\operatorname{Re} A$ (an infant), ${ }^{157}$ the integrity of immigration decisions was protected from surveillance by means of wardship; and in $\operatorname{Re} X$ (a minor), ${ }^{158}$ freedom of publication (which could cause an adolescent gross psychological damage) was said to override any interests the child might have. All three decisions are consistent with authority, and each has since been followed. ${ }^{159}$

Since Lord Denning's retirement family law has seen major changes and we can but speculate how he would have reacted. He would clearly have approved of child support legislation and the sentiments of the Family Law Act 1996 (its mediation provisions were presaged by his own recommendations nearly half a century earlier). Whether he would be as happy with the very different policies of the Children Act 1989 is less likely.

A study of Lord Denning's family law decisions throws light on much besides the law itself. We learn about his working personality and his thinking processes. And his decisions in family matters are a microcosm of his concerns elsewhere. They reveal Lord Denning at his most typical. His populist sense of justice may lead to some indefensible decisions and some wayward reasoning and also to some inconsistency. But, on the whole, the real good he has done outweighs any injustices he has caused. Without Lord Denning family law would have been more rigid and less sensitive; more oriented to rights than to needs and welfare and the interests of the weak. It would also be less committed to the patriarchy. The contradictions remain: a harbinger of, and catalyst for, reform and at the same time a bastion of reaction. It is unnecessary to resolve these conflicts: Lord Denning is, and will remain, a living paradox.

\footnotetext{
${ }^{155}$ Supra n.53 at p.583

${ }^{156}$ [1970] 1 W.L.R. 483 (though not a wardship case, it may be treated as such since the principles are identical).

${ }^{157}$ [1968] 2 All E.R. 149.

${ }^{158}$ [1975] Fam. 47.

${ }^{159}$ See in general A v. Liverpool City Council [1982] A.C. 363.
} 